\title{
Shunt infection in a single institute: a retrospective study
}

\author{
Bing Qin", Gao Chen and Jingyin Chen
}

\begin{abstract}
Background: Shunt infection (SI) is a dreaded and major complication in the management of hydrocephalus after cerebral fluid shunts. We reviewed retrospectively shunted for hydrocephalus during the last 2 years to evaluate the incidence of $\mathrm{Sl}$, including the risk factors and types of infection.

Methods: Patients who had undergone a shunt operation from January 2013 to December 2014 in our hospital were observed, study clinical data and a 6-24 months follow-up. Patients with infection complications were found and investigated.

Results: Among 343 cases of shunt surgery performed in our hospital, 6-24 months follow-up was done. 13 patients (10 men and 3 women) were found shunt infections, 11 (3.7\%) were post-operation of ventriculo-peritoneal shunt and 2 (4.2\%) of lumbo-peritoneal shunt.92.3\% cases of shunt infections were present within 2 months after shunt surgery, gram positive cocci accounted for $90 \%$ of the bacteria. After different surgery and antibiotic treatment, 8 patients became better and 5 worse.

Conclusions: The data in our single institution shows no significant differences between sex and shunt surgery. Infections more likely to present within the first 2 months after shunt placement, and gram-positive cocci account for a great proportion in detected bacteria.
\end{abstract}

Keywords: Shunt infection, Ventriculo-peritoneal shunt, Lumbo-peritoneal shunt, Bacteria

\section{Background}

Cerebral fluid shunt as one of the most common and effect treatments for hydrocephalus has last for nearly 60 years. However, various complications associated with shunt procedure have been wildly reported. Despite the advent of surgical techniques, imaging techniques, new materials and antibiotics, shunt infection is still a serious complication companion with high morbidity. Once happened, fever, meningitis, abscess, shunt dysfunction, acute hydrocephalus may present in patients, to some extent, it is another catastrophe towards patients and their family. Therapy for it is usually experimental and the outcomes differ greatly. We concluded the clinical data in a single institute in recent 2 years and reviewed previous papers.

\footnotetext{
* Correspondence: daheqin@126.com

Department of Neurosurgery, the Second Affiliated Hospital of Zhejiang

University, School of Medicine, Hangzhou, China
}

\section{Methods}

This retrospective study including 13 patients with infection complications secondary to shunt operations, between January 1st,2013 and December 31th,2014, in the Department of Neurosurgery from the 2nd Affiliated Hospital of Zhejiang University, School of Medicine. Bucharest 357 patients were treated with V-P shunt (ventriculo-peritoneal shunt) or L-P shunt (lumbo-peritoneal shunt), exclude 14 cases lost to follow-up, occurred in $3.8 \%(13 / 343)$ cases.

We collected a total of 357 patients, aged 6-84 years, with an average of 53 years, from a single center of our hospital during 2013.1.1 to 2014.12.31. There were 14 cases lost to follow-up, and the other cases were followed up for 6-24 months (13.6 months on average). There were 343 patients, aged 6-84 years old, the average age was 53.1, including 207 male and 136 female, and the average was 52.5 and 54.3 respectively. A routine follow-up of these patients was done, including 11

(c) The Author(s). 2018 Open Access This article is distributed under the terms of the Creative Commons Attribution 4.0 International License (http://creativecommons.org/licenses/by/4.0/), which permits unrestricted use, distribution, and 
cases of death in 6 months after surgery and the followup was terminated.

We observed patients symptoms during the follow-up period, then physical examination and laboratory tests were performed on patients with abnormal symptoms due to various reasons, in order to find positive cases. Shunt infection was defined by either microbiological determination of presence of bacteria in a culture or Gram stain of CSF, wound swab, and/or pseudocyst fluid or shunt erosion (visible hardware) or abdominal pseudocyst (even without positive culture) [1], the data also include patients with apparent peritonitis or/and meningitis and obviously high white blood cell count(> $50 / \mathrm{uL}$ ) and neutrophils proportion, decreased sugar level and increased protein level in cerebrospinal fluid. 13 cases $(3.8 \%)$ were found infected at last. Our team analyzed the postoperative infection cases and studied some previous literature, tried to do some discussion.

\section{Results}

\section{Groups comparison}

There were 13 cases post-operation infected. The average age was 45.5 years. 10 cases are male, the rest 3 are female, the average age was 46.1 and 43.3 years old respectively. In 343 cases, 295 cases had V-P shunt, while 11 cases infected; 48 cases underwent L-P shunt, and 2 cases positive (Table 1).

\section{Cases data}

In 13 cases of infection, there are 3 cases of pathogenic bacteria is not clear, according to the state of the cerebrospinal fluid clear infection. Among the other 10 cases, Staphylococcus aureus in 4 cases, epidermidis Staphylococcus in 2 cases, 1 cases of Staphylococcus capitis, 1 cases of Staphylococcus sciuri, Enterococcus faecium in 1 case, and 1 case of Baumanii. We focused on these 13 cases, the basic situation, the operation mode, the infection of bacteria, the symptoms appear, and the related treatment plan and prognosis are show in Table 2.

\section{Discussion}

Although much development has been made in neuroendoscopic surgery, the most common treatment for hydrocephalus remains shunt. We collected data in our unit to show the clinical characteristics of infection

Table 1 Comparation of different sex and different surgical method

\begin{tabular}{lllllllll}
\hline & male & & & & female & sum \\
\cline { 2 - 3 } & V-P & L-P & sum & & V-P & L-P & sum & \\
\hline total & 180 & 27 & 207 & & 115 & 21 & 136 & 343 \\
Infected & 9 & 1 & 10 & & 2 & 1 & 3 & 13 \\
\hline
\end{tabular}

complications secondary to shunt operations. In 357 cases collected, 350 are over 16 years old, additionally, all the 13 infected cases are adults.

Bacteria can track along the catheter into the brain, hence, the brain is susceptible to infection after shunt placement. Recently, some researches showed antibioticimpregnated shunt catheters can reduce the infection rate significantly, but still controversy. Postoperative shunt infections were reported occur in $0.3-17 \%[2,3]$ of cases in most neurosurgical institutes.

In our unit, V-P shunt and L-P shunt are routine surgical options, we noticed there is no significant differences in age, gender, and infective complication between the groups underwent different operations (Table 1). V-P shunt is the most common treatment for hydrocephalus, but a large number of reports suggest that L-P shunt is an effective shunting procedure in communicating hydrocephalus. But there is no study compelling enough to prove which shunt surgery has less complications, so if L-P shunt can be an alternative to V-P shunt remains controversial $[4,5]$.

We noticed that post-operation of head trauma seems more likely to be infected. In our study, head trauma before shunt makes a rate of 53.8\% (7/13) of infected cases. They all had underwent an operation for injury, sometimes debridement operation was needed when there was an open wound. In 2 cases, other shunt surgery was done before the shunt operation in our hospital. So undergoing surgery more recently may cause more easily to suffer an infection in the following shunt, we speculate the CSF not clear enough is the main reason.

Most cases of shunt infections are present within the first 2 months (up to 92.3\%) after the shunt surgery. This situation is similar to other reports by different authors. Atiqur Rehman introduces their study in which 10 cases appear infection in 111 post operation of V-P shunt cases, the clinical symptoms appears in 2 months accounts $70 \%$ [6]. Florian and Fried aim that infections symptomatic rapidly after shunt insertion, $70 \%$ of them being diagnosed within the first month. By 9 months $90 \%$ of shunt infection became clinical manifested $[7,8]$. We suggest that define 2 months after the shunt operation as an early stage to make a more close follow up. The infection cases in this stage are usually a surgical related infection, often appears a fever, headache, obstruction, and need to remove the shunt devices and use antibiotics.

There is no persuasive guideline to shed light on the timing and whether to remove the shunt device once the infection happened [9]. Scheffler et al. [10] compared three approaches in cure rate, morbidity and mortality, suggest that shunt removal, external ventricular drainage placement or ventricular taps and antibiotics, followed by creation of a new shunt when CSF sterility is 


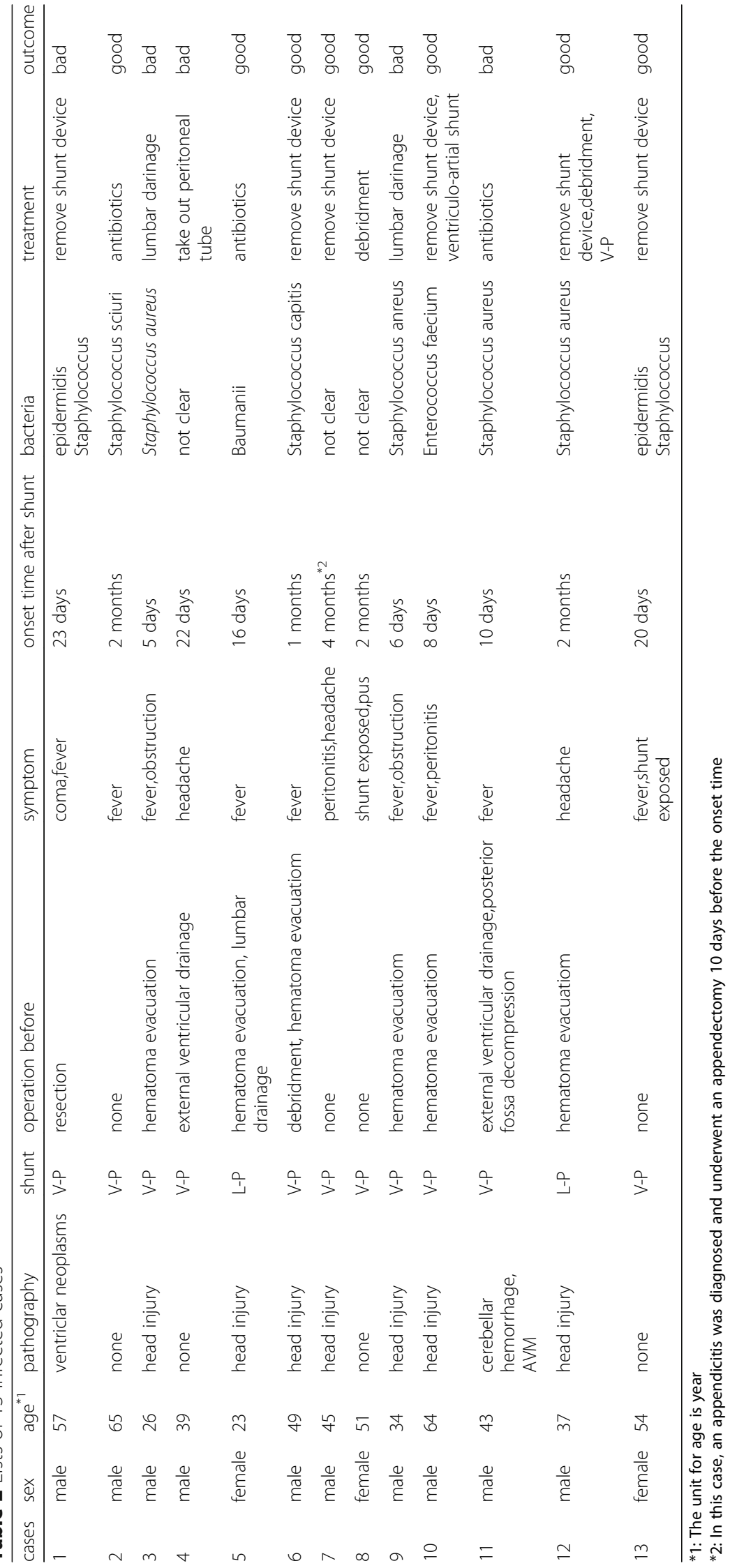


achieved, is the most effective method of treatment for CSF shunt infection. In our study, $83.3 \%(5 / 6)$ has a good outcome after totally removing catheters, in contrast, only $42.9 \%(3 / 7)$ has a good outcome while not completely removed shunt devices.

Gram positive cocci were the most common bacteria in infective complication once a shunt is placed. In 10 cases which pathogenic bacteria are clearly identified, gram positive cocci accounted for 90\% (9/10), and $80 \%$ $(8 / 10)$ is staphylococcus. These bacteria are parasitic on the skin, which is very easy to be brought into the CSF or adhesive in the shunt device, sometimes in the catheters or the valves. As a result, the infection symptoms appear in a very short time after the shunt surgery in these cases.

The treatment of infective complication typically includes systemic intravenous antimicrobials, 13 cases were all given intravenous antimicrobials. Gram positive cocci has a relatively high morbidity of infection, so we experimentally started out with vancomycin (0.5-1.0 g twice a day), or linezolid ( $0.6 \mathrm{~g}$ twice a day) in instead. Sometimes cephalosporins carbapenems was used as a combination drug. Some authors suggest using intraventricular antibiotics as while intraventricular vancomycin has a superior safety profile with no clinically significant toxicity reported [11]. A study show significantly reduces infection rates after intraventricular antibiotics treatment compared with systemic use alone, they reported a 93\% success rate in treating CSF shunt-associated infections caused by coagulasenegative Staphylococcus with intraventricular vancomycin and systemic therapy alone, without surgical intervention [12].

In our hospital, we have a general operating procedures may help reduce infection: preoperative antibiotics, double gloving and the shortest exposure time of shunt devices-—which means the operation presents skull drilling to dural or open to lumbar spinous process, abdomen incised to the peritomeum and establish the subcutaneous sinus for shunt tube, at last take out the shunt devices to perform the ventricular or lumbar puncture and place the tube into the abdomen. Recently, many studies spare no effort in how to avoid a shuntassociated infection or reduce the infect rate. They suggest methods to reduce infection including preoperative systemic antibiotics and specific surgical protocol. This includes limited access to the operating room and performing the procedure in the early morning to reduce bacterial presence in the environment. To minimize contamination, a so-called no-touch technique is adopted with antibiotic solution wound irrigation, double gloving [6], and antibiotic-impregnated shunt usage [13]. However, whether the antibiotic-impregnated shunt is effective still has a lot of controversy. There are evidences as well to discredit the benefits of antibiotic- impregnated shunt devices $[3,14]$. Further investigation is still needed.

\section{Conclusions}

The overall date, which contains 357 cases and a twoyear follow-up, shows no significant differences between sex and shunt surgery. In this single institution review, we find that SI is more likely to present within 2 months after procedure is made, so we propose that this period as an early stage to have an intensified observation. Gram-positive cocci is the most common bacteria found in infected patients after the placement of a shunt, our results showed gram positive cocci accounted for $90 \%$ $(9 / 10)$, and $80 \%(8 / 10)$ is staphylococcus.

\section{Abbreviations}

CSF: Cerebrospinal fluid; L-P shunt: Lumbo-peritoneal shunt; V-P

shunt: Ventriculo-peritoneal shunt

\section{Acknowledgements}

We acknowledgements of the case room of the Second Affiliated Hospital of Zhejiang University, School of Medicine, for help collect case data.

\section{Funding}

Not applicable.

\section{Availability of data and materials}

The datasets generated during and/or analysed during the current study are available from the corresponding author on reasonable request.

\section{Authors' contributions}

BQ collected information, statistics and write the paper. Professor GC modify and revise. JC help to collect information. All authors read and approved the final manuscript.

\section{Ethics approval and consent to participate}

Ethical approval for this investigation was obtained from the Research Ethics Committee, the Second Affiliated Hospital of Zhejiang University, School of Medicine.

\section{Consent for publication}

Formal consent has been obtained from all patients involved in the study and they have all agreed to publish their clinical information and data.

\section{Competing interests}

The authors declare that they have no competing interests.

Received: 1 May 2017 Accepted: 2 April 2018

Published online: 07 May 2018

\section{References}

1. Simon TD, Butler J, Whitlock KB, Browd SR, Holubkov R, Kestle JR, Kulkarni AV, Langley M, Limbrick DD Jr, Mayer-Hamblett N, Tamber M, Wellons JC 3rd, Whitehead WE, Riva-Cambrin J, Hydrocephalus Clinical Research N. Risk factors for first cerebrospinal fluid shunt infection: findings from a multicenter prospective cohort study. J Pediatr. 2014;164:1462-8.

2. Park MK, Kim M, Park KS, Park SH, Hwang JH, Hwang SK. A retrospective analysis of Ventriculoperitoneal shunt revision cases of a single institute. J Korean Neurosurg Soc. 2015;57:359-63.

3. Ritz R, Roser F, Morgalla M, Dietz K, Tatagiba M, Will BE. Do antibioticimpregnated shunts in hydrocephalus therapy reduce the risk of infection? An observational study in 258 patients. BMC Infect Dis. 2007;7:38.

4. Singh A, Vajpeyi IN. Comparative study of lumboperitoneal shunt versus ventriculoperitoneal shunt in post meningitis communicating hydrocephalus in children. Neurol India. 2013;61:513-6.

5. Menger RP, Connor DE Jr, Thakur JD, Sonig A, Smith E, Guthikonda B, Nanda A. A comparison of lumboperitoneal and ventriculoperitoneal 
shunting for idiopathic intracranial hypertension: an analysis of economic impact and complications using the Nationwide inpatient sample. Neurosurg Focus. 2014;37:E4.

6. Rehman AU, Rehman TU, Bashir HH, Gupta V. A simple method to reduce infection of ventriculoperitoneal shunts. J Neurosurg Pediatr. 2010;5:569-72.

7. Popa F, Grigorean VT, Onose G, Popescu M, Strambu V, Sandu AM.

Laparoscopic treatment of abdominal complications following ventriculoperitoneal shunt. J Med Life. 2009;2(4):426-36.

8. Fried AH, Epstein MH. Childhood hydrocephalus: clinical features, treatment, and the slit-ventricle syndrome. Neurosurg Q. 1994;4:51-65.

9. Simon TD, Hall M, Dean JM, Kestle JR, Riva-Cambrin J. Reinfection following initial cerebrospinal fluid shunt infection. J Neurosurg Pediatr. 2010;6:277-85.

10. Schreffler RT, Schreffler AJ, Wittler RR. Treatment of cerebrospinal fluid shunt infections: a decision analysis. Pediatr Infect Dis J. 2002;21:632-6.

11. Wilkie MD, Hanson MF, Statham PF, Brennan PM. Infections of cerebrospinal fluid diversion devices in adults: the role of intraventricular antimicrobial therapy. J Inf Secur. 2013;66:239-46.

12. Brown EM, Edwards RJ, Pople IK. Conservative management of patients with cerebrospinal fluid shunt infections. Neurosurgery. 2006;58:657-65. discussion 657-665

13. Parker SL, Attenello FJ, Sciubba DM, Garces-Ambrossi GL, Ahn E, Weingart J, Carson B, Jallo Gl. Comparison of shunt infection incidence in high-risk subgroups receiving antibiotic-impregnated versus standard shunts. Childs Nerv Syst. 2009;25:77-83. discussion 85

14. Ragel BT, Browd SR, Schmidt RH. Surgical shunt infection: significant reduction when using intraventricular and systemic antibiotic agents. J Neurosurg. 2006;105:242-7.

Ready to submit your research? Choose BMC and benefit from:

- fast, convenient online submission

- thorough peer review by experienced researchers in your field

- rapid publication on acceptance

- support for research data, including large and complex data types

- gold Open Access which fosters wider collaboration and increased citations

- maximum visibility for your research: over $100 \mathrm{M}$ website views per year

At BMC, research is always in progress.

Learn more biomedcentral.com/submissions 